\title{
Part Two, Introduction: The Renewal of the Miracle
}

\author{
Yehoyada Amir
}

\section{The Decline of Miracle-Faith}

Surprise, a slice sense of perplexity, sometimes even frustration. These are quite common reactions on listening to some modern symphonies, and they arise, in particular, when reaching the first tones and sentences of the second chapter. Have we not already been introduced to the assumed "point of departure" of the entire work? Has the composer not presented the melody, rhythm, and musical and spiritual mood that will prevail throughout the entire musical work? Have we not adjusted our ears and souls to this fresh new music - a totally unfamiliar path - while nevertheless knowing that these very new tones, themes, and musical discourse will eventually become an integral part of the "All" of that symphony? We are hence called upon to digest it gradually. First, to encounter that which the new chapter is bringing; and only then to ask how these seemingly alien paths meet and integrate in the All that these two chapters, as well as the ones to come, create.

The same experience awaits the reader of the Star. Part I created a demanding, coherent, and thoughtful environment. If carefully followed and confronted, it made its own sense. Firstly, it offered a harsh and principled critique of

How to cite this book chapter:

Amir, Y. 2021. Part Two, Introduction: The Renewal of the Miracle. In: Brasser, M., Bojanić, P. and Ciglia, F. P. (eds.) The Star for Beginners: Introductions to the Magnum Opus of Franz Rosenzweig. Pp. 71-82. London: Ubiquity Press. DOI: https://doi .org/10.5334/bco.g. License: CC-BY 
Idealistic philosophy "from Ionia to Jena" (p. 18) ${ }^{123}$ - from the beginning of preSocratic philosophy to that of Hegel and beyond. Idealism is ill-conceived and misleading since it presumes that being and thinking are identical, and hence argues that the only legitimate point of departure for systematic, philosophic thinking is the empty nothing [Nichts]. Secondly, Part I offered a "healthy" and valid alternative philosophy: one that would actually provide a systematic account that which the primary life-experience intuitively knows and believes. At the heart of that philosophy lay two foundations. The first is that philosophy in no way begins with empty nothing, but rather with that which is given by "the experience of factuality prior to all of actual experience's matters of fact," 124 its task is not to create the being but to reconstruct it - to offer a convincing, full, and systematic account of that which we know and experience. The second foundation is that philosophy's point of departure must be plural rather than singular: its "problems" should be rather than one "nothing" three "nothings" [Nichts] - those of God, man, ${ }^{125}$ and the world. Rosenzweig emphasized that confronting each of these three and unfolding each of these facts should be done in a parallel and isolated way. Part I offered a careful and challenging work with these three separate points of departure, to the extent that the reader holds "something" of God, of man and of the world. These theoretical "somethings" correlate more or less to the major aspects of ancient world pagan culture. The closing discussion of Part I offered a sincere critique of the clear limitations of that which this part achieved. Yes, it offered "pictures" of God, Man, and the world, but these pictures are totally isolated from each other, closed in their own spheres. By developing them, philosophy indeed responded systematically to our intuitive belief in God, in Man, and in the world. Nevertheless, the account it succeeded in offering in no way matches our belief. We know these three as interrelating and revealed; Part I portrayed them as hidden and isolated, and

${ }^{123}$ Citations from the Star are given from Barbara Galli's translation, unless otherwise indicated; the page number is cited within the text.

${ }^{124}$ Franz Rosenzweig, "The New Thinking", Philosophical and Theological Writings, Tr. By Paul W. Franks \& Michael L. Morgan, Indianapolis \& Cambridge: Hackeltt, 2000, p. 135. "The New Thinking" (1925) is a late retrospective on that which the Star is developing. Scholars disagree concerning the extent to which the philosophic stand expressed in this article is indeed identical to that of the systemic book, but I find this expression fruitful for its comprehension.

125 The German word Mensch Rosenzweig uses is gender-inclusive and refers equally to man (Mann) and woman (Frau). This is also the case, though not systematically, with the Hebrew word אדם, which Rosenzweig, when referring to the Biblical Creation narrative, translates by Mensch. English does not offer such a term, and all the translations of Rosenzweigian texts use the gender-exclusive word man. This chapter follows this convention, but I wish to emphasize that it does not do full justice to Rosenzweig's discourse. 
accordingly what it achieved is insufficient. Something new should be brought into the system in order to overcome this deadlock.

The first paragraphs of the introduction to Part II indeed bring something new and unexpected. Nevertheless, the reader should ask herself how this new discussion relates to the discourse of Part I and to its philosophic argumentation and insights. The best strategy for dealing with this perplexing question is suspension. Let us first understand what is going on in the new discussion, what is the inner logic of the new "music" to which we are exposed. Only once we have digested the new path we are invited to pursue may we ask how this part relates to the "music" of the previous one; how the new problems, argumentations, and insights help solve the enigmas left to us by the previous part.

The specific question Rosenzweig raises from the very first sentences of his introduction, concerns a substantial shift in the status and role religious thought - theology, religious literature, religious consciousness - attributes to miracles. He identifies a major change that occurred in this regard in the last generation, seemingly across the board of Western religions and theologies, affecting the heart of religious faith. For classic religious argumentations, miracles were anchor and rock. They proved the authenticity and validity of "our" faith and grounded the divinity of "our" Revelation. Miracles were major "summa contra gentiles" pleading, and to a no lesser extent a profound "summa theological” pillar.

When Augustine or another Church Father had to defend the divinity and the truth of revealed religion against the attacks and doubts of the pagans, they seldom missed the opportunity to refer to miracles ... $[\mathrm{T}]$ hey were its most powerful argument. For, it could well be that the pagan magicians also turned their rods into snakes; the rod of Moses swallowed the rods of idol worshippers. His own miracles were even more miraculous than the miracles of the adversary (p. 104).

No more. Modern religious consciousness appears to have lost this anchor. For modern believers, miracles were no longer stable, self-evident facts assuring the strength and undeniable nature of religious tradition. The miracle-stories tradition tells became questionable elements to be defended or abandoned. At best, tradition-loyalists hold to the belief in the miracles their tradition transmits for the sake of their loyalty. At worst, they are embraced by the load of these narratives, undermine them, award them a naturalizing interpretation, or simply depart from them. For Rosenzweig, this process is a powerful given, a substantial characteristic of our time's spirit. His question is: why? What stands behind this dramatic shift? How did intellectual and religious consciousness change to leave no more room for miracle? What does this tell us about contemporary religion? Should it simply be accepted?

In order to respond to this question, Rosenzweig must first offer his understanding of the nature of miracle altogether, and firstly, as seen by classic 
"theology," namely by the central Jewish and Christian scriptures. He claims that the heart of the notion of miracle is not so much its supernatural character, its deviation from normal rules of nature. What makes the miracle is that an extraordinary occurrence was foreseen and prophesized. A miracle is therefore a fulfilled promise.

[T] he miraculous character of miracle rested on ... the fact that it was predicted. Miracle is a "sign" ... [Singular miracle not] stand out more due to its unusual character - this is only "make up" and not core, although this unusual trait may often be most useful for the effect it produces, but no, miracle stands out because it is predicted. That a man could lift the vail that commonly extends over the future, this is miracle ... Miracle and prophecy go together. (p. 104-105)

The Hebrew Bible portrays the Exodus from Egyptian slavery and the Sinai event as a fulfillment of the promise, to the Patriarchs in the first place and later to the suffering Israelites. The entire Exodus event is predicted and prophesized by God, and only as such it can serve as the basis for the covenant with His people. A Christian reading of the Bible similarly depicts the Christus-event as foreseen and promised - by the Hebrew prophets as well as by the Sibyls. It is a true and formative revelation because it was prophesized. It is a fulfilled promise, anchored in the beginnings of the Creation narrative. Magical acts, too, are "unusual" and break the regular laws of nature. Magicians seek to force natural reality and to overcome its limitations. Magic acts may seem like miracles, but there is an essential difference: they brake the Divine law of nature, while foreseen miracles manifest Divine providence. Miracle and prophecy are the two historical stages constituting that on which pre-modern theology relied, that which classic Christian and Jewish religiosity believed to be a cornerstone of their reliability. We believe, in part, because miracles proved the authenticity, divine nature and undeniability of our faith.

Miracles, in their dual stages - promise fulfillment, are historical in nature across two interrelating layers. A miracle itself is a testimony that gives witness to faith and to the faith-community and its guides. And the reliability attributed to the story of the miraculous event depends on the personal reliability of the direct and indirect conveyers of the word, as well as on the historical context of the event and its testimony.

[Miracle] needed witnesses ... All forms of juridical proofs are found here: the weakest is proof by circumstantial evidence, the strongest comprise testimony by oath and interrogation by torture ... For the proof of the miracle, it is ... fundamental to go back to eyewitnesses. In their hearing under oath, it is personal credibility, the judgement of their capacity for observation, and even their numbers that are 
decisive $^{126} \ldots[\mathrm{T}]$ he testimony adhered to during the tortures of the interrogation is an absolute guarantee; the witness who spills his blood is the true witness. Thus, reference to the martyrs is the greatest proof of the miracle, and above all the martyrs whose torture was to confirm the quality of eyewitness, but later, the appeal to the subsequent martyrs as well: by spilling their blood, they demonstrated the solidness of their faith in the credibility of those who transmitted the miracle to them ${ }^{127}$ ... finally became a single proof in Augustine's famous appeal from all reasons based on the present, historical phenomenon, the auctoritas ecclesiae... (pp. 106-107)

The decline of miracle's role for modern theology, the fact that not secularists alone but rather also persons of faith and of faith-ful thought lost their appetite to base faith on the miracle-stories, means that the perception of the past has gone through major shift, that history does not play anymore the same role its used to. This is a decisive change in human consciousness, and to a certain extent also a dangerous one. It is therefore essential to analyze the reasons and forces behind it.

It is common to attribute that shift to enlightenment, secularization, and modern science. Rosenzweig distinguishes between three stages and characteristics of enlightenment. Ancient enlightenment was philosophical in nature. It gave rise to mediaeval discussions that strive to bridge miracle narratives with their notions of Divinity and its "general providence." Secondly, in the context of the Renaissance, enlightenment dramatically changed the perception of nature and its laws. It challenged specific miracle narratives, striving to imbue them with a natural explanation. Most powerful in that sense is the nineteenthcentury "enlightenment of history" that challenges altogether the historicity of traditions, scripture, and myths. Though all three did play a certain role in shaking the miracle-faith, none of them could bring about the essential and

${ }^{126}$ Rosenzweig refers to a popular argument brought in mediaeval Jewish philosophy, attempting to prove the superiority of the Jewish narrative of Revelation. Contrary to the "empty tomb" visited by two individuals, brought as cornerstone evidence for Christ's resurrection, the Hebrew Sinai narrative reports the presence of hundreds of thousands of participating witnesses (see, for example: Yehudah ha-Levi, The Kuzari, 1:9; Norbert Max Samuelson, "Halevi and Rosenzweig on Miracles," in: David Blumenthal (ed.), Approaches to Judaism in Medieval Times, Atlanta: Scholars Press, 1984, Vol. I, pp. 157-173).

127 The martyr is portrayed here as the supreme witness, for spilling blood and giving life for the sake of his/her testimony. In the last 'book' of the 'Star' (III:3) Rosenzweig will update this distinction and will portray as supreme witness, that which an individual or community verifies in their entire life. 
across-the-board undermining of the notion of miracle. At the heart of the nullification of miracle-faith lies a substantial inner transition within faith. Rather than anchoring its authority, authenticity, and truth in a sacred formative past, it turned to an attempt to ground them in personal religious experience (Erlebnis), ${ }^{128}$ in the present. Luther changed only the kind of authoritative past to which Christians adhere. For him, it was sola scriptura that conveyed to the present-day Christian community the word of God and His revealed will, rather than the history of the Church and its sacred writings and Dogmas. It was still the past that constituted religious life. Centering faith in the presence, in religious experience, and in its power to lead to moral progress and redemptive future, this new form of faith found its first powerful representative at the end of eighteenth century in the teachings of Friedrich Schleiermacher:

With Schleiermacher, this whole system found its classical representative dedicated as it was to denying the permanent value of the past and to anchoring the always present experience of the feeling of belief in the eternal future of the moral world. (p. 110)

This new faith, intertwined with the philosophical and theological notions of progress, of a mandatory, constant move forward, made the past a problem. It was no longer relevant as a formative anchor for values, commandments, and convictions. It was no longer sacred and superior. The past needed to be interpreted in a manner that would give the present and future their full space. From this point on, the miracle was useless. It gave witness to an irrelevant past and strived to anchor that which no-one needed any more. The shift now concerned not merely miracles, specific narratives told by traditions, but rather the very notion of miracle. It indeed seemed as though there was no more possibility to experience the miracle.

Contrary to the prevailing Idealistic philosophy so firmly attacked and negated by Rosenzweig, his perception of Erlebnistheologie is delicate and careful. He shares some of its basic intuitions and insights. He adheres to the demand "to maintain ... the primacy of hope" and to "a faith, that is personal and ex-perienced in the moment [momenthaft er-fahrenen], oriented on the pole of certitude that 'the kingdom of the ideal will finally come'" (p. 112).

128 The German word Erlebnis, as distinct from regular experience [Erfahrung], hints etiologically to the strong connection between life [Leben] and experience. Barbara Galli, the translator of the Star into English, invented the term "life experience" in order to transmit this richness of expression, one normal English could not provide. In this article, I use alternately her term and the standard one, experience, or the original Erlebnis. The same connection was emphasized by the creation of the Hebrew new term הויח, invented at the beginning of the twentieth century by the philosopher A.D. Gordon, a close ally and teacher of Martin Buber. His usage of the word life-perception maintains the same interrelated poles of life [היים] and experience. 
The primacy of the present, anchoring both past and future in the primordial experience of Revelation, lies at the heart of the Star. In this sense, Rosenzweig is very close to the position Martin Buber would express a few years later when speaking about "religion as presence;" ${ }^{29}$ when placing at the heart of human life a dynamic, occurring "relation" [Beziehung] between the I and the You. ${ }^{130}$ Rosenzweig shares the intuition that "facts" and "objects" belong to the past, constituting a sphere of non-relational truth.

If he will strive to renew the formative role of a "past," and hence of the miracle, this will in no way imply the simple restoration of pre-modern naive notions, of a non-critical reading of the scriptures - Christian and Jewish alike. He refers neither to the miracles nor to historical past, but rather to the miracle, ${ }^{131}$ the notion of miracle, and to the ultimate past, namely the notion of Creation. Erlebnistheologie presents revelation, cannot give up past-based factuality; religiosity based on personal experiencing should in no way abandon truth; miracle-faith substantiated Jewish and Christian religious conviction in the old days. A new way to the miracle must be found.

\section{Integrity and Objectivity}

It is time now to turn back and set the argumentations developed in this introduction in their wider context within the Star; to zoom in and consider the meaning of this discussion in light of Part I. As stated above, we left Part I understanding that philosophy - the "healthy"132 and valid one Rosenzweig

${ }^{129}$ Martin Buber first expressed his emerging dialogical philosophy in the series of lectures he gave in 1922 at Rosenzweig's Lehrhaus, entitled: "Religion als Gegenwart" [Religion as Presence]. A year later, this discussion received its complete formulation in his famous book I and Thou, which he saw as the point of departure for his entire philosophical work (see; Rivka Horwitz, Buber's Way to 'I and Thou, Philadelphia, New York and Jerusalem: Jewish Publication Society, 1988.

${ }^{130}$ Contrary to the You [Thou], the It belongs to the past and has no part in the present-event.

131 Both English translations of the Star (Galli and Hallo) mistranslate the title of the introduction to Part II by referring to miracles in the plural, whereas Rosenzweig actually speaks about "the miracle" [das Wunder].

132 The notion that Idealism is "sick" while the philosophy Rosenzweig constructs is "healthy" manifests itself in the fullest sense in Rosenzweig's later Das Büchlein vom gesunden und kranken Menschenverstand (1912). Rosenzweig never published the book, which he considered too popular. It was published for the first time in 1955 in Nahum Glatzer's translation, under the title "Understanding the Sick and the Healthy" (see: Yehoyada Amir, "Rosenzweig's Büchlein vom gesunden und kranken Menschenverstand as a prolegomena”, in: Yehoyada Amir, Yossi Turner, \& Martin Brasser (eds.) 
himself develops -is still "insufficient." It suffers from two essential shortcomings: First, it is a philosophy of Viewpoint [Standpunkt], a reaction of an individual philosopher to her/his life-experience rather than a scientific system. As such, it offers a "worldview" (or even a "life-view") rather than objective philosophy. Second, it is capable only of constituting "pictures" of God, man, and the world as isolated and hidden; it does not succeed in giving an account of them as we actually know them and believe in them: revealed and interrelating.

These are the elements of our world, but we do not know the world this way; this is the world we believe in, but we do not believe in it as it is presented to us here. We know a living movement, an electric circuit in which these elements swim; now they are pulled out of this current ... we no longer recognize them (p. 93).

As we have seen, these substantial shortcomings are grounded in the very nature of the philosophy Rosenzweig believes to be healthy and valid, and therefore cannot be overcome by philosophy itself.

A similar situation concerns the introduction to Part II regarding Erlebnistheologie, the prevailing kind of modern religiosity, one that Rosenzweig both shares and criticizes. He holds firm "the primacy of hope, or, more precisely, a faith that is personal and ex-perienced in the moment, oriented on the pole of certitude that 'the kingdom of the ideal will finally come'" (p. 112). Nevertheless, he would in no way give up grounding this very present-experience on truth, on factuality; he refuses to abandon the ethos of witnessing; he insists on returning to centrality of the miracle. Experiencing God's revealed love is in no way merely psychological; ${ }^{133}$ it is a real encounter between the God we know and believe in and the man we are aware of; it occurs in and carries a redeeming message for the real world in which we live.

[T]ruth cannot be denied, not even in the name of the ideal, let alone in the name of lived experience. Truth is and remains the solid ground on which alone authentic experience can grow, where alone the ideal can be verified. The miracle of the personal experience of Revelation may be strengthened, for the will, in the certitude of its future confirmation through Redemption; but cognition wants to see another foundation on which that experience rests, including when it throws that anchor of hope (p. 117).

Faith, Truth, and Reason: New Perspectives on Franz Rosenzweig's 'Star of Redemption,' Freiburg \& München, 2012, pp. 37-60).

${ }^{133}$ In his later article Die Schrift und Luther, Rosenzweig compares the assumption that religious experience is merely psychological to the attempt to find the stars within the telescope, simply because we see them through this instrument (Zweistromland [GS 3], p. 760). 
Theology must find a stable basis that can ground the life experience of revelation. It is only philosophy, viewed now as "Creation,"134 that can provide such a grounding in factuality and award experience with truth:

Theology ... calls in philosophy ... in order, theologically speaking, to throw a bridge from Creation to Revelation ... From the theological point of view, what philosophy must accomplish for it is ... its anticipation, or more accurately, its foundation, the exhibiting of the preconditions on which this content rests. And since theology itself does not its content as content, but as event - that is to say not as life, but as lived experience - the pre-conditions are not conceptual elements, but existing reality; in the place of philosophical concept of truth, therefore, the notion of Creation arises for it. Philosophy contains the entire content of Revelation in this way, but it does possess this content as Revelation, so not as revealed, but as created content. In Creation, Revelation is - "foreseen" in its entire content, exactly in accordance with today's notion of faith, hence including Redemption. Philosophy, as the theologian practices it, becomes the prediction for Revelation ... [B] efore our astonished eyes, Revelation ... gains its character of authentic miracle authentic, for it becomes wholly the fulfillment of the promise that took place in Creation. (p. 117-118)

Philosophy needs theology to a no lesser extent. As a viewpoint, philosophy is dependent on the point of view of the philosopher and can never overcome subjectivity and its non-scientific and aphoristic quality unless that viewpoint acquires the quality of objectivity. This can be achieved only once the one philosophizing is a receiver of an ultimate and objective message:

The man as receiver of Revelation, carrying its faith-content in her/his life experience .... is the only possible philosopher of the new philosophy. Philosophy today requires ... for its scientific character, that "theologians" do philosophy. (p. 116; slightly different translation than Galli’s)

${ }^{134}$ Rosenzweig refers to the terms Creation, revelation and Redemption in two interrelating meanings. On the one, expanded sense Creation is identified with philosophy, dealt with in part I; Revelation - the entire content of part II; and Redemption - the supreme encountering with eternity and truth, to be dealt with in part III. The more restricted sense of these terms, as dealt with in details in the books of part II, is Creation as the specific relationship between God and the world; Revelation - the encounter between man and God; Redemption - the work of Man and the world on each other. The usage of the terms in the introduction to part II, and hence in this article, is in accordance with the expanded, former meaning. 
Philosophy requires theologians for whom Revelation, the dialogue between the ultimate-objectivity of the Divine and the pure subjectivity of the human is the presence experience.

This mutual need of theology and philosophy forms the basis for the miracle. Viewing philosophy as Creation, namely as grounding and foreseeing Revelation, as well as viewing Revelation as a fulfilled promise grounded by the factuality philosophy has established, are in no way necessary logical outcomes of either of these. They are a free decision, indeed the essential decision that constitutes the entire system of the Star and revives "the possibility to experience the miracle." ${ }^{135}$

The decision to intertwine philosophy and theology, Creation and Revelation, is the act of faith-ful cognition [gläubigen Wissen] the Star conveys. ${ }^{136}$ Once we make this decision, once we adopt this epistemological stance, the miracle actually happens. Creation, the ultimate past beyond all layers of historical past, is the promise, foreseeing Revelation. Revelation is indeed a fulfillment of the promise inherent in Creation. Philosophy, as an anticipating theology, gains its objectivity; theology, grounded in the truth and factuality of philosophy, is imbued with integrity. Miracle is therefore neither proved nor proving any claim. It is merely experienced.

Miracle, in its renewed epistemological sense, is the pivotal point of the Star. It portrays the framework for the complex relationships between Parts I and II, offering the two alternating points of departure for the entire system: approving life in the shade of death-fear; and being anchored in the experience of Revelation. Miracle also serves as the methodological key to the detailed discussions of the three "events" discussed in Part II's books, opening and revealing God, man, and the world. In all the points of this discussion, Rosenzweig makes creative use of the idea that the relationship between the closed, isolated images of God, man, and the world in Part I, and their interrelating, revealed appearance in Part II, is that of a fulfilled promise. Promise and fulfillment are identical in content yet of opposing directions: a complete, fully-ended element transmutes into a beginning, a point of departure for something new. The specific contents of the "pictures" of God, man, and the world developed and portrayed in Part I, reappear in Part II's books in a reversed manner. Thus the rebellious and proud pole of the notion of man reappears in Part II, in the context of Revelation, as humility; its origin as independent defiance as well as its transmission to humility establish the figure of the beloved sole, the receiver of Revelation.

135 The title of the introductions to the various parts speak in a profound Kantian manner about "possibilities." Here: Über die Möglichkeit das Wunder $\mathrm{zu}$ erleben [On the Possibility to Experience the Miracle]. At first Rosenzweig planned to award the introduction with the title "On the Possibility to experience God" (Gritli Briefe, letters from 31 Aug. 1918; 4 Oct. 1918).

136 Zweistromland, (Gs 3), p. 835. 
The same is true of every pole of the "pictures" of the three isolated elements of Part I as they encounter each other in Part II.

Miracle is therefore an epistemological decision. It realizes itself in the Star's system of faith-ful cognition. Nevertheless, it is not merely theoretical, but manifested in the multifaceted appearance of language.

[L]anguage, as it is entirely there, entirely created, yet only awakens to its real life in Revelation. And so there is nothing new in the miracle of Revelation ... it is entirely sin, entirely a making visible and a becoming audible of the Providence originally hidden in the mute night of Creation, entirely - Revelation. Revelation is therefore always new only because it is immemorially old. It renews the immemorial Creation into the ever newly created present because that immemorial Creation itself is already nothing other than the sealed prediction that God renews from day to day the work of the beginning The word of man is symbol: at every moment it is newly created in the mouth of the one speaks, yet only because it is from the very beginning and already bears within its womb each speaker who one day brings about the miracle of renewal in it. $($ p. 121) 137

\section{Further Reading (Annotated List)}

Leora F. Batnizky, Idolatry and Representation: the Philosophy of Franz Rosenzweig reconsidered, Princeton: Princeton University Press, 2000, pp. 32-62 [especially 40-47].

* Batnizky gives full account of Rosenzweig's notion of the import of miracle-faith and witnessing in Jewish existence. She does not refer to miracle-faith's role for the building of Rosenzweig's system neither to the place of miracle and its renewal in Christian environment and hence in overall Western culture.

Paul Mendes Flohr, "Rosenzweig's concept of miracle," in: Jens Mattern, Gabriel Motzkin \& Shimon Sandbank (eds.), Jüdisches Denken in einer Welt ohne Gott: Festschrift für Stéphane Mosès, Berlin: Vorwerk, 2000, pp. 53-66.

* Mendes Flohr follows my reading of the introduction (though failing to mention his sources) and sets it in the wider context of modern Jewish philosophic discourse.

137 Compare Benjamin's note that “'God created' is a potential miracle, not an actual one. The actual miracle is God's speech, which transforms and thus fulfills what is already given" (Mara H. Benjamin, Rosenzweig's Bible: Reinventing Scripture for Jewish Modernity, Cambridge: Cambridge University Press, 2009, p. 49). 
Renate Schindler, "Das Wunder: Paradigma geschichtlicher Ewigkeit”, in: Zeit Geschichte Ewigkeit in Franz Rosenzweigs 'Stern der Erlösung,' Berlin: Parerga, 2007, pp. 199-229.

* Schindler gives a systematic account about the role of miracle in in constructing the relationship between philosophy and theology, close to the interpretation given here. She includes extensive references to previous scholars' perceptions.

Francesco Paolo Ciglia, Auf der Spur Augustins. Confessiones und De civitate Dei als Quellen des Stern der Erlösung, in: Rosenzweig als Leser. Konzeptuelle Kommentare zum «Stern der Erlösung», Max Niemeyer Verlag, Tübingen 2004, S. 233-244. 